\title{
The MMPs Genes Polymorphisms: Potential Role in Pharmacogenomics and Target Therapy
}

\section{Ferdinando Mannello*}

Section of Cell Biology-Clinical Biochemistry, Dept of Biomolecular Sciences, University "Carlo Bo", 61029 Urbino, Italy

The evidence that individual characteristics play an important role in physiological and pathological processes has resulted in the targeted study of genetic polymorphisms in the clinical setting. In this context, mediators that degrade the extracellular matrix (ECM), such as Matrix Metalloproteinases (MMPs) are focused in studies involving inflammatory and degenerative diseases, and principally the prognosis and metastasis of cancer [1].

MMPs have important roles in different physiological and pathological processes, as they regulate various cell processes such as angiogenesis, cell proliferation, apoptosis, alteration of cell motility, effects on the immune system and host defence, modulation of the bioactivity of chemokines [2,3], and connective tissue remodeling associated with cancer invasion and metastasis, cartilage destruction in arthritis, atherosclerotic plaque rupture, and the development of aneurysms [4].

In addition to a remarkably common 3-D structure [3,5], MMPs share a similar gene arrangement, suggesting that they arose by duplications of an ancestor gene. At least eight of the known human MMP genes (MMP-1, -3, -7, -8, -10,-12,-13 and -20) are clustered on chromosome 11 at 11q21-23. Other MMP genes are scattered among chromosomes $1,8,12,14,16,20$, and 22 [6].

Recently, naturally occurring sequence variation (DNA polymorphisms) has been detected in the promoter of several MMP genes, controlling gene transcription [3].

DNA polymorphism represents natural sequence variants (alleles), which may occur in more than one form. These appear in at least $1 \%$ of a population and are considered biologically normal, and have been estimated to occur on the average at one in every 1000 base pairs throughout the human genome [4,7].

Approximately $90 \%$ of DNA polymorphisms are single-nucleotide polymorphisms (SNPs) due to a single base substitution [8].

Apart from SNPs, there are minisatellite (0.1-20 kb long) and microsatellite ( $0.1 \mathrm{~kb}$ long) polymorphisms which result from variation in the number of tandem repeats of DNA sequence. The majority of microsatellite polymorphisms occur at di-nucleotide repeat sequences, such as (CA)n repeats. Generally, SNPs are bi-allelic whereas microsatellite polymorphisms are multi-allelic [4].

Although the majority of DNA polymorphisms in MMPs genes are probably functionally neutral, a proportion of them can exert allele specific effects on the regulation of gene expression by altering the interaction between transcription factors and transcription-binding sites in the corresponding promoters, resulting in higher or lower transcriptional activity of the coded protein and having dual roles in disease $[3,4]$, which may contribute to inter-individual differences in various biological phenotype traits, to increased susceptibility to the development of different pathologies and their prognosis [1], such as coronary heart disease, abdominal aortic aneurysm, and cancers
[4], likely through effects on the balance between the synthesis and degradation of extracellular matrix proteins and to differential response to pharmacological agents.

Many studies described in literature have suggested a correlations between single nucleotide polymorphisms of MMPs genes with several no cancer diseases and cancers [1], such as: lung cancer, head and neck cancer, renal cancer, esophageal cancer, colorectal cancer and breast cancer [9-12] (Table 1).

Furthermore, it is important to consider that MMP polymorphisms may not occur as independent events and could be associated with other polymorphisms in the genome, forming an haplotype $[1,56]$. Haplotypes are a combination of alleles at multiple loci that are transmitted together on the same chromosome. The interaction of different MMPs SNP induce an additive effect and increase the susceptibility to developing a disease, such as in the case of MMP8, MMP-10, MMP-3 and MMP-14 polymorphism association in Ulcerative Colitis [57]. A previous study suggested that genetic variations in the MMP family, including MMP-1, $-3,-8,-12$ and -9 , are associated with bladder cancer risk [56] whereas the haplotype +6727 C: +6767 G: $+7096 \mathrm{~T}:+8153 \mathrm{G}$ of MMP-14 gene might contribute to the prediction of susceptibility and pathological development of Oral Squamous Cell Carcinoma [58].

Also other studies suggested that the $\mathrm{C}(-1306)-\mathrm{C}(-735)$ haplotype in the MMP-2 promoter contributes to risk of the occurrence and metastasis of esophageal squamous cell carcinoma by increasing expression of MMP-2 [22].

Haplotype effects may provide more complete and reliable information than single polymorphism analysis, which may contribute only partially to the MMP pathway [56].

Despite genomic studies coupled to functional analysis of promoter regions of MMP genes have already provided important information about the molecular mechanisms controlling their expression in health and disease these genetic approaches to MMP function are limited by poor methodology in many studies [1]. Further progress will depend

*Corresponding author: Ferdinando Mannello, Unit of Cell Biology, Section of Clinical Biochemistry, Department of Biomolecular Sciences, University "Carlo Bo", Via O. Ubaldini 7, 61029 Urbino (PU), Italy, Tel: +39-0722-351479; Fax: +39-0722-322370; E-mail: Ferdinando.mannello@uniurb.it

Received January 23, 2012; Accepted January 24, 2012; Published January 26 2012

Citation: Mannello F (2012) The MMPs Genes Polymorphisms: Potential Role in Pharmacogenomics and Target Therapy. J Pharmacogenom Pharmacoproteomics 3:e114. doi:10.4172/2153-0645.1000e114

Copyright: (c) 2012 Mannello F. This is an open-access article distributed unde the terms of the Creative Commons Attribution License, which permits unrestricted use, distribution, and reproduction in any medium, provided the original author and source are credited. 


\begin{tabular}{|c|c|c|c|c|}
\hline \multirow{2}{*}{ Gene } & \multirow{2}{*}{ Polymorphisms } & \multirow{2}{*}{$\begin{array}{l}\text { Promoter } \\
\text { Activity }\end{array}$} & \multicolumn{2}{|c|}{ Associated pathology } \\
\hline & & & Tumor disease & Non tumor disease \\
\hline MMP1 & $-16071 \mathrm{G} / 2 \mathrm{G}$ & Higher & $\begin{array}{l}\uparrow \text { Risk: lung [13] and colorectal [14] cancer, } \\
\text { renal cell carcinoma [15] } \\
\text { Poor prognosis: breast [16] and ovarian [17] } \\
\text { cancer, cutaneous malignant melanoma [18] }\end{array}$ & $\begin{array}{l}\uparrow \text { Risk: idiopathic pulmonary fibrosis [19] } \\
\text { Poor prognosis: cirrhosis [20] }\end{array}$ \\
\hline \multirow{3}{*}{ MMP2 } & $-1575 \mathrm{G} / \mathrm{A}$ & Lower & Breast cancer [21] (in vitro MCF-7 cells) & \\
\hline & $-1306 \mathrm{C} / \mathrm{T}$ & Lower & $\begin{array}{l}\downarrow \text { Risk: esophageal[22] and lung [23] cancer, } \\
\text { gastric cardia adenocarcinoma [24], oral } \\
\text { squamous cell carcinoma [25] }\end{array}$ & $\downarrow$ Risk: lumbar disc disease [26] \\
\hline & $-735 \mathrm{C} / \mathrm{T}$ & Lower & $\downarrow$ Risk: esophageal [22] and lung [23] cancer & \\
\hline MMP3 & $-11715 \mathrm{~A} / 6 \mathrm{~A}$ & Lower & $\begin{array}{l}\downarrow \text { Risk: lung [27], breast [28] and oral [29] } \\
\text { cancer }\end{array}$ & $\begin{array}{l}\uparrow \text { Risk: atherosclerosis [30], myocardial } \\
\text { infarction [31], aortic aneurysm [32] } \\
\text { Poor prognosis: rheumatoid arthritis [33] }\end{array}$ \\
\hline MMP7 & $-181 \mathrm{~A} / \mathrm{G}$ & Higher & $\begin{array}{l}\uparrow \text { Risk: gastric [34], cervical [35] and oral [36] } \\
\text { cancer, esophageal squamous cell carcinoma } \\
\text { and non-small cell lung carcinoma [37] }\end{array}$ & Poor prognosis: atherosclerosis [38] \\
\hline \multirow{3}{*}{ MMP8 } & $-799 \mathrm{C} / \mathrm{T}$ & Higher & Better prognosis: breast cancer [39] & $\begin{array}{l}\uparrow \text { Risk: preterm premature rupture of } \\
\text { membrane (haplotype) [40] }\end{array}$ \\
\hline & $-381 \mathrm{~A} / \mathrm{G}$ & Higher & & $\begin{array}{l}\uparrow \text { Risk: preterm premature rupture of } \\
\text { membrane (haplotype) [40] }\end{array}$ \\
\hline & $+17 \mathrm{C} / \mathrm{T}$ & Higher & $\downarrow$ Risk: lung cancer [41] & $\begin{array}{l}\uparrow \text { Risk: preterm premature rupture of } \\
\text { membrane (haplotype) [40] }\end{array}$ \\
\hline \multirow{3}{*}{ MMP9 } & $-1562 \mathrm{C} / \mathrm{T}$ & Higher & $\uparrow$ Risk: oral cancer $[42,43]$ & $\begin{array}{l}\uparrow \text { Risk: atherosclerosis [44], abdominal aortic } \\
\text { aneurysm [45], myocardial ischemia [46], } \\
\text { schizophrenia [47], bipolar mood disorders } \\
{[48,49] \text {, varicose vein [50] }}\end{array}$ \\
\hline & $(\mathrm{CA}) \mathrm{n}$ & Higher $>20$ & $\uparrow$ Risk: bladder cancer [51] & $\begin{array}{l}\uparrow \text { Risk: carotid atherosclerosis [52], multiple } \\
\text { sclerosis [53] }\end{array}$ \\
\hline & Microsatellite & CA repeats & & $\begin{array}{l}\text { Cerebral aneurysm [54], age-related } \\
\text { macular degeneration [55] }\end{array}$ \\
\hline MP12 & $-82 \mathrm{~A} / \mathrm{G}$ & Lower & Poor prognosis: bladder cancer [51] & \\
\hline
\end{tabular}

Table 1: Functional polymorphism in MMPs promoters.

on improved methods, including larger sample sizes, genotyping of haplotypes rather than single-nucleotide polymorphisms, better matching of cases and controls and, importantly, replicating positive findings in a second independent population before publication [31] extend these regulatory studies on MMPs to other levels of control including those based on epigenetic or miRNA-mediated mechanisms to clarify the relevance of these alterations in complex diseases such as cancer [1].

Such genetic polymorphisms are important because they can be used as biomarkers that herald various diseases and thus facilitate early intervention in patients at high risk [3], indeed polymorphisms in MMP genes has been shown to influence therapy outcomes by altering signaling pathways. Advances in genome technology and their comprehensive and systematic deployment to elucidate the genomic basis of MMP differences promise to ultimately enhance the efficacy of chemotherapy while reducing its toxicity for the treatment of various cancers [59].

The MMPs genes polymorphisms in clinical medicine is gaining increasing attention in identifying genetic region or genes implicated in common complex diseases and traits such as Central Nervous System disorders, cancer and cardiovascular diseases [56]. A major application of SNP efforts is using small variations in genes sequences as markers for defining populations exhibiting a given phenotype. Thus the major derivers for the SNP efforts in health care are defining genetic regions and targets for therapeutics, stratifying patient populations according to expression of SNP markers (and corresponding biological phenotype), and positioning drugs into the appropriate sub sectors of patient populations.

Harping on SNPs of MMPs promoters and better understanding the potential pharmacogenomics role, will give a fruitful return in the form of better understanding of complex diseases by deciphering metabolic pathways, reduction of drug toxicity, development of predictive genetic test and this will lead ultimately to the development of individualized medicine prescribing practices [60].

The impact of genetics on medicine will be even more widespread. The pharmacogenomics approach for predictive drug responsiveness will be standard practice for quite a number of disorders and drugs. New gene based "designer drugs" will be introduced in the market for diabetes mellitus, hypertension, mental illness and many other conditions. Improved diagnosis and treatment of cancer will likely be the most prominent clinical consequences of genetics. A vast amount of molecular information can be collected about the genetic basis of malignancy and on that basis every tumor will have a precise molecular fingerprint [61]. Cataloging the enzyme isoforms and their new cellular localization, the gene polymorphisms and the unexpected pathways involved [62], therapy will be individually targeted to that fingerprint 
[63]. Many of the diseases can be identified where common variants in genes involved in drug metabolism [64] or drug action [65] are associated with the likelihood of a good or bad response [66].

\section{References}

1. Fanjul-Fernández M, Folgueras AR, Cabrera S, López-Otín C (2010) Matrix metalloproteinases: Evolution, gene regulation and functional analysis in mouse models. Biochim Biophys Acta 1803: 3-19.

2. Cauwe B, Van den Steen PE, Opdenakker G (2007) The biochemical, biological, and pathological kaleidoscope of cell surface substrates processed by matrix metalloproteinases. Crit Rev Biochem Mol Biol 42: 113-185.

3. Arakaki PA, Marques MR, Santos MCLG (2009) MMP-1 polymorphism and its relationship to pathological processes. J Biosci 34: 313-320.

4. Ye S (2000) Polymorphism in matrix metalloproteinase gene promoters: implication in regulation of gene expression and susceptibility of various diseases. Matrix Biol 19: 623-629.

5. Massova I, Kotra LP, Fridman R, Mobashery S (1998) Matrix metalloproteinases: structures, evolution, and diversification. FASEB J 12: 1075-1095.

6. Shapiro SD (1998) Matrix metalloproteinase degradation of extracellular matrix: biological consequences; Curr. Opin. Cell Biol. 10: 602-608.

7. Sherry ST, Ward M, Sirotkin K (1999) dbSNP-database for single nucleotide polymorphisms and other classes of minor genetic variation. Genome Res 9: 677-679

8. Ra HJ, Parks WC (2007) Control of matrix metalloproteinase catalytic activity. Matrix Biol 26: 587-596.

9. Peng B, Cao L, Ma X, Wang W, Wang D, et al. (2010) Meta-analysis of association between matrix metalloproteinases 2,7 and 9 promoter polymorphisms and cancer risk. Mutagenesis 25: 371-379.

10. Peng B, Cao L, Wang W, Xian L, Jiang D, et al. (2010) Polymorphisms in the promoter regions of matrix metalloproteinases 1 and 3 and cancer risk: a metaanalysis of 50 case-control studies. Mutagenesis 25: 41-48.

11. McColgan $P$, Sharma $P$ (2009) Polymorphisms of matrix metalloproteinases 1 , 2,3 and 9 and susceptibility to lung, breast and colorectal cancer in over 30,000 subjects. Int J Cancer 125: 1473-1478.

12. Zhou P, Du LF, Lv GQ, Yu XM, Gu YL, et al. (2011) Current evidence on the relationship between four polymorphisms in the matrix metalloproteinases (MMP) gene and breast cancer risk: a meta-analysis. Breast Cancer Res Treat 127: 813-818.

13. Zhu Y, Spitz MR, Lei L, Mills GB, Wu X (2001) A single nucleotide polymorphism in the matrix metalloproteinase-1 promoter enhances lung cancer susceptibility. Cancer Res 61: 7825-7829.

14. Woo M, Park K, Nam J, Kim JC (2007) Clinical implications of matrix metalloproteinase- $1,-3,-7,-9,-12$, and plasminogen activator inhibitor-1 gene polymorphisms in colorectal cancer. J Gastroenterol Hepatol 22: 1064-1070.

15. Hirata H, Okayama N, Naito K, Inoue R, Yoshihiro S, et al. (2004) Association of a haplotype of matrix metalloproteinase (MMP)-1 and MMP-3 polymorphisms with renal cell carcinoma. Carcinogenesis 25: 2379-2384

16. Przybylowska K, Kluczna A, Zadrozny M, Krawczyk T, Kulig A, et al. (2006) Polymorphisms of the promoter regions of matrix metalloproteinases genes MMP-1 and MMP-9 in breast cancer. Breast Cancer Res Treat 95: 65-72.

17. Six L, Grimm C, Leodolter S, Tempfer C, Zeillinger R, et al. (2006) A polymorphism in the matrix metalloproteinase-1 gene promoter is associated with the prognosis of patients with ovarian cancer. Gynecol Oncol 100: 506510 .

18. Ye S, Dhillon S, Turner SJ, Bateman AC, Theaker JM, et al. (2001) Invasiveness of cutaneous malignant melanoma is influenced by matrix metalloproteinase 1 gene polymorphism. Cancer Res 61: 1296-1298.

19. Checa M, Ruiz V, Montano M, Velazquez-Cruz R, Selman M, et al. (2008) MMP-1 polymorphisms and the risk of idiopathic pulmonary fibrosis. Hum Genet 124: 465-472.
20. Okamoto K, Mimura K, Murawaki Y, Yuasa I (2005) Association of functional gene polymorphisms of matrix metalloproteinase (MMP)-1, MMP-3 and MMP9 with the progression of chronic liver disease. J Gastroenterol Hepatol 20: 1102-1108.

21. Harendza S, Lovett DH, Panzer U, Lukacs Z, Kuhnl P, et al. (2003) Linked common polymorphisms in the gelatinase A promoter are associated with diminished transcriptional response to estrogen and genetic fitness. J Biol Chem 278: 20490-20499.

22. Yu C, Zhou Y, Miao X, Xiong P, Tan W, et al. (2004) Functional haplotypes in the promoter of matrix metalloproteinase-2 predict risk of the occurrence and metastasis of esophageal cancer. Cancer Res 64: 7622-7628.

23. Zhou Y, Yu C, Miao X, Wang Y, Tan W, et al. (2005) Functional haplotypes in the promoter of matrix metalloproteinase-2 and lung cancer susceptibility. Carcinogenesis 26: 1117-1121.

24. Miao X, Yu C, Tan W, Xiong P, Liang G, et al. (2003) A functional polymorphism in the matrix metalloproteinase-2 gene promoter $(-1306 \mathrm{C} / \mathrm{T})$ is associated with risk of development but not metastasis of gastric cardia adenocarcinoma. Cancer Res 63: 3987-3990.

25. Lin SC, Lo SS, Liu CJ, Chung MY, Huang JW, et al. (2004) Functional genotype in matrix metalloproteinases-2 promoter is a risk factor for oral carcinogenesis. J Oral Pathol Med 33: 405-409.

26. Dong DM, Yao M, Liu B, Sun CY, Jiang YQ, et al. (2007) Association between the $-1306 \mathrm{C} / \mathrm{T}$ polymorphism of matrix metalloproteinase-2 gene and lumbar disc disease in Chinese young adults. Eur Spine J 16: 1958-1961.

27. Fang S, Jin X, Wang R, Li Y, Guo W, et al. (2005) Polymorphisms in the MMP1 and MMP3 promoter and non-small cell lung carcinoma in North China. Carcinogenesis 26: 481-486.

28. Ghilardi G, Biondi ML, Caputo M, Leviti S, DeMonti M, et al. (2002) A single nucleotide polymorphism in the matrix metalloproteinase-3 promoter enhances breast cancer susceptibility. Clin Cancer Res 8: 3820-3823.

29. Vairaktaris E, Yapijakis C, Vasiliou S, Derka S, Nkenke E, et al. (2007) Association of -1171 promoter polymorphism of matrix metalloproteinase-3 with increased risk for oral cancer. Anticancer Res 27: 4095-4100.

30. Djuric T, Zivkovic M, Radak D, Jekic D, Radak S, et al. (2008) Association of MMP-3 5A/6A gene polymorphism with susceptibility to carotid atherosclerosis. Clin Biochem 41: 1326-1329.

31. Abilleira S, Bevan S, Markus HS (2006) The role of genetic variants of matrix metalloproteinases in coronary and carotid atherosclerosis. J Med Genet 43 897-901.

32. Lamblin N, Bauters C, Hermant X, Lablanche JM, Helbecque N, et al. (2002) Polymorphisms in the promoter regions of MMP-2, MMP-3, MMP-9 and MMP12 genes as determinants of aneurysmal coronary artery disease. J Am Col Cardiol 40: 43: 48.

33. Mattey DL, Nixon NB, Dawes PT, Ollier WE, Hajeer AH (2004) Association of matrix metalloproteinase 3 promoter genotype with disease outcome in rheumatoid arthritis. Genes Immun 5: 147-149.

34. Kubben FJ, Sier CF, Meijer MJ, van den Berg M, van der Reijden JJ, et al (2006) Clinical impact of MMP and TIMP gene polymorphisms in gastric cancer. Br J Cancer 95: 744-751.

35. Singh H, Jain M, Mittal B (2008) MMP-7 (-181ANG) promoter polymorphisms and risk for cervical cancer. Gynecol Oncol 110: 71-75.

36. Vairaktaris E, Serefoglou Z, Yapijakis C, Vylliotis A, Nkenke A, et al. (2007) High gene expression of matrix metalloproteinase-7 is associated with early stages of oral cancer. Anticancer Res 27: 2493-2498.

37. Zhang J, Jin X, Fang S, Wang R, Li Y, et al. (2005) The functional polymorphism in the matrix metalloproteinase-7 promoter increases susceptibility to esophageal squamous cell carcinoma, gastric cardiac adenocarcinoma and non-small cell lung carcinoma. Carcinogenesis 26: 1748-1753.

38. Jormsjo S, Whatling C, Walter DH, Zeiher AM, Hamsten A, et al. (2001) Allele specific regulation of matrix metalloproteinase-7 promoter activity is associated with coronary artery luminal dimensions among hypercholesterolemic patients. Arterioscler Thromb Vasc Biol 21: 1834-1839. 
Citation: Mannello F (2012) The MMPs Genes Polymorphisms: Potential Role in Pharmacogenomics and Target Therapy. J Pharmacogenom Pharmacoproteomics 3:e114. doi:10.4172/2153-0645.1000e114

39. Decock J, Long JR, Laxton RC, Shu XO, Hodgkinson C, et al. (2007) Association of matrix metalloproteinase-8 gene variation with breast cancer prognosis. Cancer Res 67: 10214-10221.

40. Wang H, Parry S, Macones G, Sammel MD, Ferrand PE, et al. (2004) Functionally significant SNP MMP8 promoter haplotypes and preterm premature rupture of membranes (PPROM). Hum Mol Genet 13: 2659-2669.

41. Gonzalez-Arriaga P, Lopez-Cima MF, Fernandez-Somoano A, Pascual $T$, Marron MG, et al. (2008) Polymorphism $+17 \mathrm{C} / \mathrm{G}$ in matrix metalloproteasi MMP8 decreases lung cancer risk. BMC Cancer 8: 378

42. Vairaktaris E, Vassiliou S, Nkenke E, Serefoglou Z, Derka S, et al. (2008) A metalloproteinase-9 polymorphism which affects its expression is associated with increased risk for oral squamous cell carcinoma. Eur J Surg Oncol 34: 450-455.

43. Tu HF, Wu CH, Kao SY, Liu CJ, Liu TY, et al. (2007) Functional -1562 C to-T polymorphism in matrix metalloproteinase-9 (MMP-9) promoter is associated with the risk for oral squamous cell carcinoma in younger male areca users. $J$ Oral Pathol Med 36: 409-414.

44. Medley TL, Cole TJ, Dart AM, Gatzka CD, Kingwell BA (2004) Matrix metalloproteinase-9 genotype influences large artery stiffness through effects on aortic gene and protein expression. Arterioscler Thromb Vasc Biol 24: 14791484.

45. Jones GT, Phillips VL, Harris EL, Rossaak JI, van Rij AM (2003) Functiona matrix metalloproteinase-9 polymorphism (C-1562T) associated with abdominal aortic aneurysm. J Vasc Surg 38: 1363-1367.

46. Morgan AR, Zhang B, Tapper W, Collins A, Ye S (2003) Haplotypic analysis of theMMP-9 gene in relation to coronary artery disease. J Mol Med 81: 321-326.

47. Rybakowski JK, Skibinska M, Kapelski P, Kaczmarek L, Hauser J (2009) Functional polymorphism of matrix metalloproteinase-9 (MMP-9) gene in schizophrenia. Schizophr Res 109: 90-93.

48. Rybakowski JK, Skibinska M, Leszczynska-Rodziewicz A, Kaczmarek L, Hauser J (2009) Matrix metalloproteinase-9 (MMP-9) gene and bipolar mood disorder. Neuromolecular Med 11: 128-132.

49. Rybakowski JK, Skibinska M, Suwalska A, Leszczynska-Rodziewicz A, Kaczmarek L, et al. (2011) Functional polymorphism of matrix metalloproteinase-9 (MMP-9) gene and response to lithium prophylaxis in bipolar patients. Hum Psychopharmacol 26: 168-171.

50. Xu HM, Zhao Y, Zhang XM, Zhu T, Fu WG (2011) Polymorphisms in MMP-9 and TIMP-2 in Chinese Patients with Varicose Veins. J Surg Res 168: 143-148.

51. Kader AK, Liu J, Shao L, Dinney CP, Lin J, et al. (2007) Matrix metalloproteinase polymorphisms are associated with bladder cancer invasiveness. Clin Cancer Res 13: 2614-2620.
52. Fiotti N, Altamura N, Fisicaro M, Carraro N, Adovasio R, et al. (2005) MMP-9 microsatellite polymorphism: association with the progression of intima-media thickening and constrictive remodeling of carotid atherosclerotic plaques. Atherosclerosis 182: 287-292.

53. Fiotti N, Zivadinov R, Altamura N, Nasuelli D, Bratina A, et al. (2004) MMP-9 microsatellite polymorphism and multiple sclerosis. J Neuroimmunol 152: 147 153

54. Peters DG, Kassam A, St Jean PL, Yonas H, Ferrell RE (1999) Functiona polymorphism in the matrix metalloproteinase-9 promoter as a potential risk factor for intracranial aneurysm. Stroke 30: 2612-2616.

55. Fiotti N, Pedio M, Battaglia Parodi M, Altamura N, Uxa L, et al. (2005) MMP-9 microsatellite polymorphism and susceptibility to exudative form of age-related macular degeneration. Genet Med 7: 272-277.

56. Munhoz FB, Godoy-Santos AL, Santos MC (2010) MMP-3 polymorphism Genetic marker in pathological processes (Review). Mol Med Report 3: 735740 .

57. Morgan AR, Han DY, Lam WJ, Triggs CM, Fraser AG, et al. (2011) Genetic variations in matrix metalloproteinases may be associated with increased risk of ulcerative colitis. Hum Immunol 72: 1117-1127.

58. Weng CJ, Chen MK, Lin CW, Chung TT, Yang SF (2011) Single Nucleotide Polymorphisms and Haplotypes of MMP-14 are Associated with the Risk and Pathological Development of Oral Cancer. Ann Surg Oncol.

59. Chetty C, Rao JS, Lakka SS (2011) Matrix metalloproteinase pharmacogenomics in non-small-cell lung carcinoma. Pharmacogenomics 12: 535-546.

60. Mannello F (2009) Matrix metalloproteinase polymorphisms and HIV antiretroviral drugs: new implications of pharmacogenomics in therapeutic approaches. Pharmacogenomics J 9: 355-357.

61. Mannello F (2011) What does matrix metalloproteinase-1 expression in patients with breast cancer really tell us? BMC Med 9: 95

62. Mannello F, Medda V (2012) Nuclear localization of matrix metalloproteinases Prog Histochem Cytochem.

63. Halim NS (2000) An early pharmacogenomics application. Scientist 14: 20-21.

64. Collins FS, McKusick VA (2001) Implications of the Human Genome Project for medical science. JAMA 285: 540-544.

65. Midorikawa Y, Tsuji S, Takayama T, Aburatani H (2012) Genomic approach towards personalized anticancer drug therapy. Pharmacogenomics 13: 191 199.

66. Wadelius M, Alfirevic A (2011) Pharmacogenomics and personalized medicine: the plunge into next-generation sequencing. Genome Med 3: 78. 